\title{
Protein and Antigenic Profile among Mycoplasma bovis Field Strains Isolated in Bosnia and Herzegovina
}

\author{
Maid Rifatbegovićn ${ }^{1}$ Patrícia Assunção ${ }^{2}$, Šemso Pašić ${ }^{1}$, \\ Christian de la $\mathrm{Fe}^{3}$, Jose B. Poveda ${ }^{2}$ \\ ${ }^{1}$ Department of Microbiology and Infectious Diseases, Veterinary Faculty, University of Sarajevo, Sarajevo, \\ Bosnia and Herzegovina \\ ${ }^{2}$ Unidad de Epidemiologia y Medicina Preventiva, Facultad de Veterinaria, Universidad de Las Palmas de Gran \\ Canaria, Arucas, Spain \\ ${ }^{3}$ Departamento de Sanidad Animal, Facultad de Veterinaria, Universidad de Murcia, Murcia, Spain
}

Received December 18, 2007

Accepted November 12, 2008

\begin{abstract}
Mycoplasma bovis is a serious, worldwide-spread but often overlooked pathogen causing respiratory disease, mastitis, and arthritis in cattle. In this study we characterize the protein and antigenic profiles of $M$. bovis field strains isolated in Bosnia and Herzegovina by sodium dodecyl sulphate polyacrylamide gel electrophoresis and immunoblotting, and analyze possible variations among these strains. Greater differences occurred when comparing field strains with the reference strain PG45. One field strain isolated from lung samples of a heifer was markedly different from strains isolated from nasal swabs taken from cattle raised in another geographic region. A possible correlation may exist between protein and antigen profiles of $M$. bovis field strains, geographic regions and anatomical sites of isolation.
\end{abstract}

Mycoplasma bovis, cattle, antigen, immunoblotting, protein, SDS-PAGE

Mycoplasma bovis is the most pathogenic bovine mycoplasma in the parts of the world considered to be free of contagious bovine pleuropneumonia. This pathogen primarily causes calf pneumonia, mastitis and arthritis. Other symptoms are seen less frequently. Diseases caused by M. bovis are found worldwide, causing significant economic losses. Yet, there are no effective control measures or standard protocols for their routine application available (Nicholas and Ayling 2003).

Although M. bovis, like other mycoplasmas, possesses a small genome size, it is still highly invasive and able to colonize organ systems. It is now clear that one of the possible explanations for its ability to avoid bodily defence mechanisms and adapt to different environments in the host is due to phenotypic variations in mycoplasmas (Wise 1993; Razin et al. 1998; Minion 2002). Rosengarten et al. (1994) demonstrated highly variable membrane surface proteins (Vsps) of $M$. bovis which represent a family of antigenically and structurally related lipoproteins. These Vsps represent the predominant antigens recognized by the host immune response during infection, and they can undergo high frequency changes in size and expression. This system is responsible for the survival of these pathogens in the presence of cytolytic antibodies and for their adaptation to specialized environments within their respective hosts (Behrens et al. 1994; Razin et al.1998). A full understanding of phenotypic variation among M. bovis strains should be of great value when developing diagnostic methods and vaccines for the control of infections caused by this organism.

Recently, M. bovis has been isolated, for the first time, in Bosnia and Herzegovina (Rifatbegović et al. 2007). The aim of this study was to characterize the protein and antigenic profile of these M. bovis field strains by SDS-PAGE (sodium dodecyl sulphatepolyacrylamide gel electrophoresis) and immunoblot and to analyze possible variations among these strains.

Address for correspondence:

Maid Rifatbegović

Department of Microbiology and Infectious Diseases

Veterinary Faculty

University of Sarajevo

Phone/Fax: +38733617370

Zamaj od Bosne, 71000 Sarajevo, Bosnia and Herzegovina 


\section{Materials and Methods}

M. bovis strains and harvesting

Eight field strains of $M$. bovis $(01,166,168,170,187,188,189,190)$ recovered in Bosnia and Herzegovina (Rifatbegović et al. 2007) were studied and compared with the reference strain PG 45 and a field strain (2/91) originating from Germany. Field strain 01 was isolated from lung samples of quarantined heifers that died from respiratory disease. The other seven strains were isolated from nasal swabs from fattened cattle with clinical signs of respiratory disease.

For SDS-PAGE and immunoblot, strains were grown in liquid medium (Thiaucourt et al. 1996) until logarithmic phase. After centrifugation at $14,000 \mathrm{~g}$ for $20 \mathrm{~min}$ at $4{ }^{\circ} \mathrm{C}$, followed by three washes with saline $(0.85 \%$ of $\mathrm{NaCl}$ in distilled water), pellets were resuspended in saline until the turbidity matched that of the McFarland no. 3 standard.

\section{SDS-PAGE}

Prior to electrophoresis the protein content of each mycoplasma sample was estimated with a commercial kit (Microprotein-PR/Sigma) following manufacturer's instructions. SDS-PAGE was performed following the procedure described by Laemmli (1970) with $1.5 \mathrm{~mm}$ thick 4\% stacking and 10\% resolving gel. Each sample containing $26 \mu \mathrm{g}$ of whole cell proteins of mycoplasmas was dissolved in lysis buffer and heated at $96{ }^{\circ} \mathrm{C}$ for 5 min. Low molecular weight marker solution (LMW - Amersham Pharmacia Biotech, UK) was prepared according to manufacturer's instructions. All samples and LMW were submitted to electrophoresis at a constant current of $20 \mathrm{~mA}$ per gel in a vertical electrophoresis unit (Biorad, Hercules, CA). Coomassie blue stain (Amersham Pharmacia Biotech, UK) was used for visualization of protein bands.

Immunoblotting

Proteins were transferred from gel to a $0.45 \mu \mathrm{m}$ nitrocellulose membrane (BioTrace NT, Pall Corporation) in a transference unit (Biorad, Hercules, CA) at $70 \mathrm{~V}$ for $90 \mathrm{~min}$ (Gonçalves et al. 1998). After the transfer, the membrane was blocked by incubating at room temperature for $2 \mathrm{~h}$ in a blocking solution $(1 \mathrm{~mol} / 1 \mathrm{glycine}, 1 \%$ egg albumin and 5\% skimmed milk in PBS). The membrane was incubated overnight at $4{ }^{\circ} \mathrm{C}$ with rabbit antisera produced against PG45 strain, diluted at $1: 200$. After washing the membrane three times with PBST (15 min) and once with PBS (10 min), secondary antibodies conjugated with peroxidase were added. The membrane washing was repeated in the same way after $1 \mathrm{~h}$ of incubation at room temperature. Once it was completed, the developing solution (4-chloro- $\alpha$-naftol $24 \mu \mathrm{g}$, methanol $8 \mathrm{ml}$, PBS $50 \mathrm{ml}, \mathrm{H}_{2} \mathrm{O}_{2} 30 \mu \mathrm{l}$ ) was added. The reaction was stopped by washing the membrane with distilled water.

\section{Results}

\section{SDS-PAGE analysis}

The electrophoretic patterns of ten $M$. bovis strains were homogeneous, with some differences in band intensity, expression and sites (Plate XI, Fig. 1). Coomassie blue stain showed 38 to 45 protein bands between 205 and $14.4 \mathrm{kDa}$, with the main proteins corresponding to molecular masses of about 86, 72, 63, 53, 48, 45, 43, 40, 38, 32 and $27 \mathrm{kDa}$.

SDS-PAGE results revealed that the reference strain PG45 had a different electrophoretic pattern when compared with the field strains. It was characterized by unique bands at 160, 147 and 30.5 $\mathrm{kDa}$, higher intensity bands in the 80,67 and $58 \mathrm{kDa}$ position and lack of proteins at 120 and 55 $\mathrm{kDa}$. The $160 \mathrm{kDa}$ band was observed also at the field strain 168 , but with very low intensity.

The main difference between the German field strain 2/91 and the other tested strains was the lack of a $58 \mathrm{kDa}$ protein and the expression of a $29 \mathrm{kDa}$ protein. Low intensity of a $86 \mathrm{kDa}$ band was characteristic of this and field strain 01.

Field strain 01 was specific with intense bands at 31 and particularly 32 and $36 \mathrm{kDa}$. The 31 and $36 \mathrm{kDa}$ bands were only observed at this strain and strain 2/91. Also, strain 01 was distinguished from others by expressing a protein at $69 \mathrm{kDa}$, and the lack of a $34 \mathrm{kDa}$ band which was expressed by other strains with different intensity.

Immunoblotting analysis

Immunoblotting analysis of the $M$. bovis strains revealed up to 36 bands, with major proteins at $72,63,48,45,43,40,38,32$ and $29 \mathrm{kDa}$. Some differences regarding antigenic expression and intensity were observed, especially in the lower $(25-16 \mathrm{kDa})$ molecular mass regions (Plate XII, Fig. 2). The reference strain PG45 was the only strain without bands at 39 and $27 \mathrm{kDa}$ positions. The lack of expression at 86 and $58 \mathrm{kDa}$ level was characteristic of reference strain PG45 and German strain 2/91. 
At 25-16 kDa position, the Bosnian field strains expressed up to seven bands. In contrast, reference strain PG45 expressed no bands at this level, and strain 2/91 expressed only low intensity band at $23 \mathrm{kDa}$. The analysis of Bosnian field strains revealed that strain 01 was unique, since it expressed prominent bands at 36 and $31 \mathrm{kDa}$, and lacked 34, 30, 29, 23 and $16 \mathrm{kDa}$ bands. Field strains 166 and 168 expressed no bands or very low intense bands at 20, 19 and $16 \mathrm{kDa}$ positions.

\section{Discussion}

We have detected protein and antigen variability among $M$. bovis strains. Seven out of eight strains isolated in Bosnia and Herzegovina had similar protein profiles obtained by SDSPAGE, but one field strain (01) showed marked differences. The main differences among field strains in comparison to protein patterns were in the intensity and expression of some bands.

Results revealed that the protein profile of the German field strain 2/91 was similar to those isolated in Bosnia and Herzegovina, particularly with strain 01. Reference strain PG45 was clearly distinguishable from all others by the presence of three specific protein bands and the lack of two.

The protein heterogeneity among field strains does not correlate with results of some authors (Sachse et al. 1992; Poumarat et al. 1994; Filioussis et al. 1999), but antigen heterogeneity has been confirmed in earlier studies (Poumarat et al. 1994; Rosengarten et al. 1994). The same is true for protein characteristics, as differences were noted between field strains and were evident for strain 01 . Also, antigen heterogeneity between the two control strains and the field strains were more marked than those obtained by SDS-PAGE. The greatest differences were obtained when comparing the reference strain PG45 with the other ones. Similar results with antigen expression patterns of PG45 strain were reported by Rosengarten et al. (1994). Specific patterns of the PG45 strain were also demonstrated by Thomas et al. (2003) who found a weak adherence rate of reference strain PG45 in contrast to other $M$. bovis strains. These differences could be a consequence of the high number of passages of the reference strain and the different storage conditions during many years of storage.

Strain 01, which was isolated from a heifer lung sample, was markedly different from the other seven field strains, which were all recovered from nasal swabs of cattle of the same farm. The heifer was from another geographic region and had only recently been imported to Bosnia and Herzegovina.

Similar results, correlating between geographic origin and antigen profile of mycoplasmas, were reported by Sols ona et al. (1996), who found that the antigen profile of M. agalactiae strains could be separated into groups according to geographic origin. Rosengarten et al. (1994) compared the protein profiles of 11 strains of M. bovis and found that one strain which had been isolated in Cuba was clearly distinguishable from the other isolates originated from Germany. However, these authors suggested that the geographical origin and site of isolation do not have an important influence on antigen heterogeneity.

This study has demonstrated phenotype heterogeneity among M. bovis Bosnia and Herzegovina strains. It has also suggested a possible link between protein and antigen profiles of $M$. bovis field strains and the geographic origin and site of isolation. Since the number of strains used in this study was not large enough to support this type of conclusion, further study is needed to confirm this correlation.

\section{Proteinový a antigenní profil terénních kmenů Mycoplasma bovis izolovaných v Bosně a Hercegovině}

Mycoplasma bovis je nebezpečný, celosvětově rozšířený, avšak často přehlížený patogen způsobující dýchací onemocnění, mastitidu a artritidu v chovech skotu. V této studii jsou 
charakterizovány bílkovinné a antigenní profily terénních typů původce $M$. bovis a jeho detekovaných přechodných variant izolovaných v Bosně a Hercegovině pomocí gelové elektroforézy a imunoblotování. Větší rozdíly byly prokázány při porovnání terénních typů $\mathrm{s}$ referenčním typem PG45. Jeden z terénních typů izolovaný z plicních vzorků jalovice byl značně odlišný od typů izolovaných z nosních výtěrů skotu chovaného v jiném zeměpisném regionu. Byla zjištěna možná korelace mezi bílkovinnou a antigenní strukturou terénních typů $M$. bovis, zeměpisnými regiony a anatomickou lokalizací odběrových míst pro izolaci tohoto patogena.

\section{References}

Behrens A, Heller M, Kirchhoff H, Yogev D, Rosengarten R 1994: A family of phase- and size- variant membrane surface lipoprotein antigens (Vsps) of Mycoplasma bovis. Infect Immun 62: 5075-5084

Filioussis G, Papanikolau E, Petridou E, Arsenakis M, Sarris K 1999: Isolation and characterization of M. bovis from calf pneumonia outbreak in Greece. In: Stipkovits L, Rosengarten R, Frey J (Eds): COST 826 - Mycoplasmas of ruminants: pathogenicity, diagnostics, epidemiology and molecular genetics. Luxembourg, Office for official publications of the European communities. Vol 3: 101-103

Gonçalves R, Regalla J, Nicolet J, Frey J, Nicholas R, Bashiruddin J, De Santis P, Goncalves AP 1998: Antigen heterogeneity among Mycoplasma mycoides subsp. mycoides SC isolates: discrimination of major surface proteins. Vet Microbiol 63: 13-28

Laemmli UK 1970: Cleavage of structural proteins during the assembly of the lead of bacteriophage T4. Nature 227: $680-685$

Minion FC 2002: Molecular pathogenesis of mycoplasma animal respiratory pathogens. Front Biosci 7: 1410-1422

Nicholas RAJ, Ayling RD 2003: Mycoplasma bovis: disease, diagnosis, and control. Res Vet Sci 74: 105-112

Poumarat F, Solsona M, Boldini M 1994: Genomic, protein and antigenic variability of Mycoplasma bovis. Vet Microbiol 40: 305-321

Razin S, Yogev D, Naot Y 1998: Molecular biology and pathogenicity of mycoplasmas. Microbiol Mol Biol Rev 62: 1094-1156

Rifatbegović M, Assunção, Poveda JB, Pašić Š 2007: Isolation of Mycoplasma bovis from the respiratory tract of cattle in Bosnia and Herzegovina. Vet Rec 160: 484-485

Rosengarten R, Behrens A, Stetefeld A, Heller M, Meike A, Sachse K, Yogev D, Kirchhoff H 1994: Antigen heterogeneity among isolates of Mycoplasma bovis is generated by high-frequency variation of diverse membrane surface proteins. Infect Immun 62: 5066-5074

Sachse K, Grajetzki C, Pfutzner H, Hass R 1992: Comparison of Mycoplasma bovis strains based on SDS-PAGE and immunoblot protein patterns. J Vet Med B-Infect Dis Vet Public Health 39: 246-252

Solsona M, Lambert M, Poumarat F 1996: Genomic, protein homogeneity and antigenic variability of Mycoplasma agalactiae. Vet Microbiol 50: 45-58

Thiaucourt F, Bolske G, Leneguersh B, Smith D, Wesonga H 1996: Diagnosis and control of contagious caprine pleuropneumonia. Rev Sci Tech Off Int Epizoot 15: 1415-1429

Thomas A, Sachse K, Dizier I, Grajetzki C, Farnir F, Mainil G, Linden A 2003: Adherence to various host cell lines of Mycoplasma bovis strains differing in pathogenic and cultural features. Vet Microbiol 91: 101-113

Wise KS 1993: Adaptive surface variation in mycoplasmas. Trends Microbiol 1: 59-63 
Plate XI

Rifatbegović M. et al.: Protein and Antigenic ... pp. 151-154

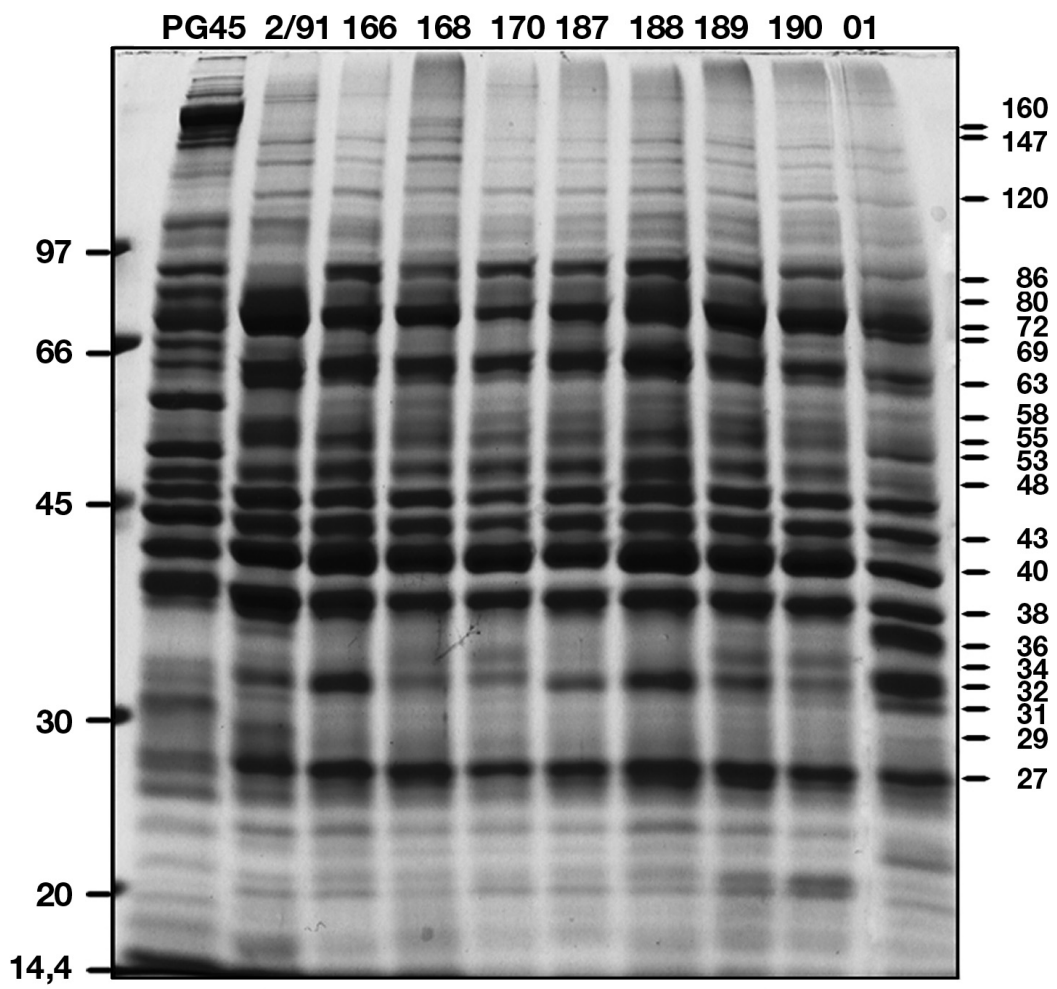

Fig 1. Coomassie blue-stained SDS-PAGE gel of whole-cell proteins from ten $M$. bovis strains (26 $\mu \mathrm{g}$ proteins loaded per track). On the top: names of the analysed strains. Positions of molecular mass standards are indicated $(\mathrm{kDa})$ on the left. Positions of major or bands with some differences in expression or intensity are indicated $(\mathrm{kDa})$ on the right. 


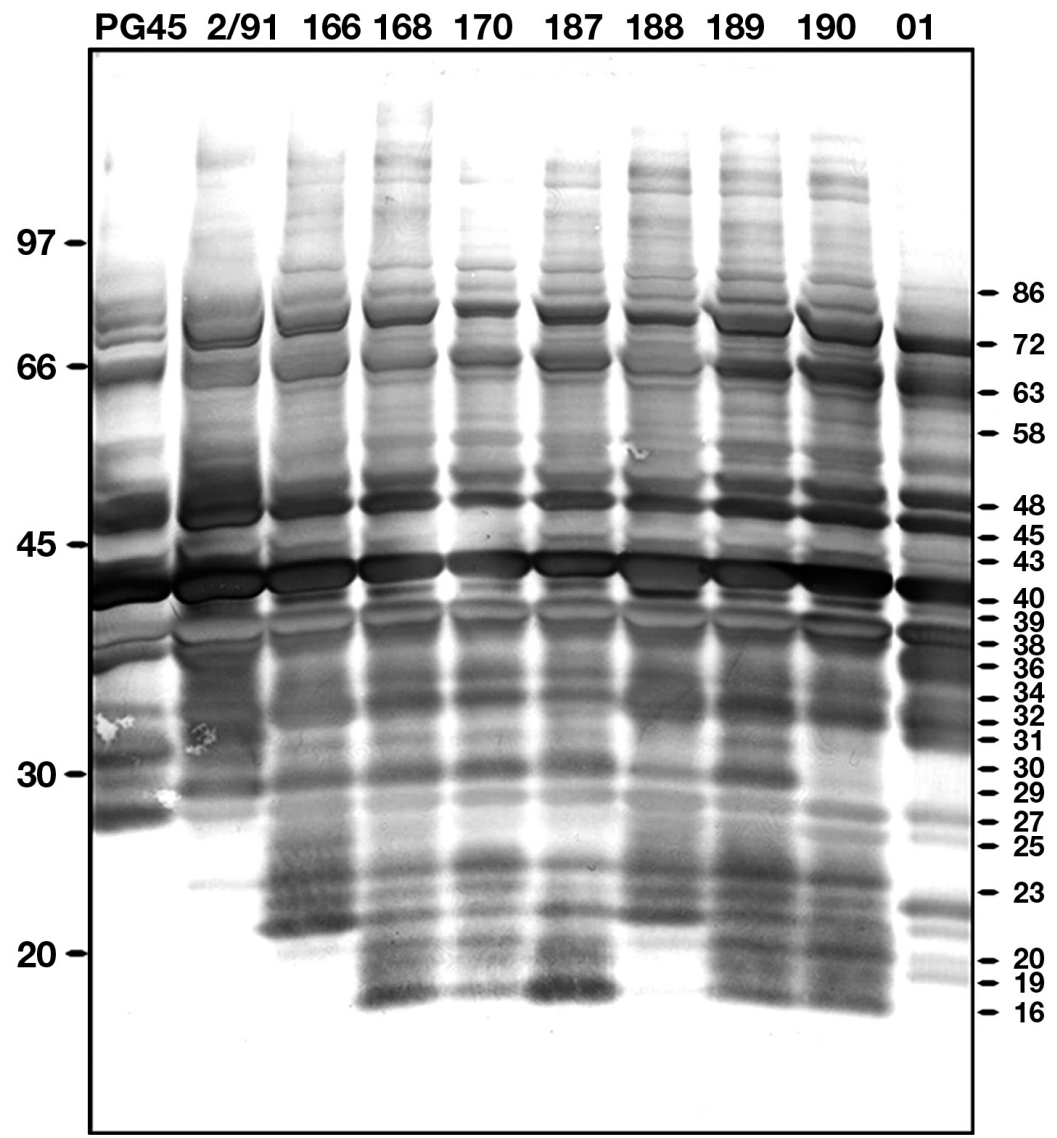

Fig 2. Immunoblot profile of $M$. bovis strains ( $26 \mu \mathrm{g}$ proteins loaded per track). On the top: names of the analyzed strains. Positions of molecular mass standards are indicated $(\mathrm{kDa})$ on the left. Positions of some bands are indicated $(\mathrm{kDa})$ on the right. 